\title{
Remediation of a mine soil with insoluble polyacrylate polymers enhances soil quality and plant growth
}

\author{
Q. Guimei, A. De Varennes \& C. Cunha-Queda \\ Department of Agricultural and Environmental Chemistry, Instituto Superior de Agronomia, Technical University of Lisbon \\ (TULisbon), Tapada da Ajuda, 1349-017 Lisboa, Portugal
}

\begin{abstract}
We investigated the effects of different application rates of insoluble hydrophilic polyacrylate polymers on plant growth and soil quality from a Pb-contaminated mine soil. The polymer increased the waterholding capacity of the soil from about $250 \mathrm{~g} / \mathrm{kg}$ in unamended soil to almost $1000 \mathrm{~g} / \mathrm{kg}$ in soil with $0.6 \%$ polymer. However, the capacity of the polymer to retain water decreased progressively, presumably as the polymer sorbed $\mathrm{Pb}$. Growth of orchardgrass (Dactylis glomerata L. cv. Amba) was stimulated in the polymer-amended soil. The greatest accumulated biomass over four cuts was obtained in soil amended with $0.4 \%$ of polymer. After orchardgrass had been growing for 101 days, the amounts of $\mathrm{CaCl}_{2}$-extractable $\mathrm{Pb}$ present in the polymer-amended soil were $15-66 \%$ of those in the unamended soil, depending on polymer application rate. The number of bacteria culturable on agar enriched with 'Nutrient' and yeast extract, and the activities of dehydrogenase, phosphatase, $\beta$-glucosidase, protease and cellulase increased following polymer application. In contrast, urease activity was impaired by polymer application, presumably due to the presence of ammonium as a counter ion. Principal component analysis was used to compare the effects of the different rates of polymer application. Overall, the application of 0.2 or $0.4 \%$ polymer resulted in closer values for the indicators of soil quality used than the treatment with $0.6 \%$ polymer.
\end{abstract}

Keywords: Orchardgrass, mine soils, polyacrylate polymers, remediation, soil quality, enzymatic activities

\section{Introduction}

The S. Domingos mine is located in the Iberian Pyrite Belt near the border between Portugal and Spain. Modern extraction of $\mathrm{Cu}$ began in the 19th century and took place until 1966 when the mine was closed because of the exhaustion of its ore. The mine tailings were left without any treatment or containment, and a large area of land (at its peak the mine occupied about $100 \mathrm{ha}$ ) is contaminated with a wide range of trace elements.

Soil contamination with trace elements affects plant growth and has toxic effects on soil organisms. When the polluted area is large, as in this case, in situ remediation technologies are usually considered. The addition of different amendments into soils precipitates or increases metal sorption therefore decreasing the proportion of the total element

Correspondence: A. de Varennes. E-mail: adevarennes@isa.utl.pt Received June 2008; accepted after revision July 2008 in soil solution. These amendments include additives used in agriculture such as lime (Geebelen et al., 2003) and organic matter (Farfel et al., 2005), and industrial products such as zeolites (Friesl et al., 2003).

In the last decade, a new technique for in situ soil remediation, based on insoluble polyacrylate polymers, was proposed (Torres \& de Varennes, 1998; de Varennes \& Torres, 1999; Lindim et al., 2001; de Varennes \& Queda, 2005; de Varennes et al., 2006).

Polyacrylate polymers are based on acrylic acid, and are composed of chains with regularly distributed carboxylic groups: $\left(-\mathrm{CH}_{2} \mathrm{CHCOOH}-\right)_{\mathrm{n}}$.

The degree of ionization of these groups depends on $\mathrm{pH}$, and the negative charges formed are neutralized by $\mathrm{Na}^{+}$, $\mathrm{K}^{+}$or $\mathrm{NH}_{4}^{+}$.

Large molecular weight insoluble polyacrylates swell to form gels that contain many times their weight in water. They are used in diapers, paper towels and feminine products. It is estimated that over $130 \mathrm{Gg}$ of polyacrylates 
are used annually in such products (Martin, 1996). Hydrophilic polymers are also marketed as 'superabsorbent polymers', with different trade names, for incorporation into soils and substrates when an increase in the water-holding capacity is desirable.

In free solution, the ionic species of several metals, including copper and zinc, are rapidly trapped within an insoluble polyacrylate polymer and not released upon subsequent incubation of the polymer particles with water (Torres \& de Varennes, 1998; de Varennes \& Torres, 2000). This capacity to chelate metal cations suggests that these polymers could be used for in situ remediation of metal-contaminated soils.

Hydrophilic insoluble polymers may enhance plant growth by three main processes:

1 increased water-holding capacity of the soil and an enhanced supply to plants (Boatright et al., 1997; de Varennes et al., 1999; Al-Humaid \& Moftah, 2007);

2 increased supply of the cation present as counter ion (Silberbush et al., 1993; de Varennes et al., 1999);

3 decreased bioavailability of trace elements (Torres \& de Varennes, 1998; Lindim et al., 2001; de Varennes \& Queda, 2005; de Varennes et al., 2006).

There is no information on the effect of polyacrylate polymers on mine soils. The objectives of this study were: to choose the rate of polyacrylate polymer to be used in the remediation of a contaminated mine soil and to determine the effect of treatments on soil quality. Several parameters related to soil quality can be used to monitor in situ remediation of contaminated sites. In this study, we chose to measure the effects of polymer application on plant biomass, bioavailable $\mathrm{Pb}$, several hydrolytic enzymatic activities related to the $\mathrm{C}, \mathrm{N}$ and $\mathrm{P}$ cycles, culturable bacteria and fungi, and soil dehydrogenase activity.

\section{Material and methods}

Soil from the S. Domingos mine was used in the experiment (Table 1). The soil was passed through a 2-mm sieve and received a basal dressing of $125 \mathrm{mg} \mathrm{P}$ and $25 \mathrm{mg} \mathrm{Mg} / \mathrm{kg}$ of soil. The nutrients were supplied as calcium dihydrogen phosphate and magnesium sulphate, respectively.

Polyacrylate polymers with $\mathrm{K}^{+}(210 \mathrm{mg} \mathrm{K} / \mathrm{g}$ of polymer) or $\mathrm{NH}_{4}{ }^{+}$(100 mg N/g of polymer) as counter ions were added at $0.1,0.2$ or $0.3 \%$ each to half of the soil. The polymers retained about $380 \mathrm{~g}$ of distilled water per grams of dry polymer. They had linear chains with molecular weights of about 40 million. The chains were not cross-linked, but joined together by physical entanglement. Fifty-five per cent of the particles had diameters over $0.5 \mathrm{~mm}$, and only $1 \%$ had diameters smaller than $45 \mu \mathrm{m}$.

The soil that received the largest amount of polymer was not supplied with additional $\mathrm{K}$ or $\mathrm{N}$, while the other treatments received potassium sulphate and ammonium nitrate to
Table 1 Characteristics of the soil used in the experiment

\begin{tabular}{lc}
\hline Texture & Sand \\
\hline Organic C $(\mathrm{g} / \mathrm{kg})$ & 1 \\
Kjeldhal-N $(\mathrm{g} / \mathrm{kg})$ & 0.3 \\
$\mathrm{pH}$ water $(1: 2.5)$ & 4.1 \\
Total $\mathrm{Cu}(\mathrm{mg} / \mathrm{kg})$ & 91 \\
Total $\mathrm{Zn}(\mathrm{mg} / \mathrm{kg})$ & 47 \\
Total $\mathrm{Pb}(\mathrm{mg} / \mathrm{kg})$ & 6200 \\
\hline
\end{tabular}

compensate for the difference in $\mathrm{K}$ and $\mathrm{N}$ supply, so that all pots received $630 \mathrm{mg} \mathrm{K}$ and $300 \mathrm{mg} \mathrm{N} / \mathrm{kg}$ of soil.

For each treatment, three replicate pots (upper diameter: $21 \mathrm{~cm}$; height: $18 \mathrm{~cm}$ ) were filled with $4 \mathrm{~kg}$ of soil. Orchardgrass (Dactylis glomerata L. cv. Amba) was sown and plant number was adjusted to 60 per pot 3 weeks later. The pots were kept in a glasshouse (minimum temperature: $15^{\circ} \mathrm{C}$; maximum temperature: $30{ }^{\circ} \mathrm{C}$ ) without supplemental lighting, and weighed at least every other day. Water was supplied when the water retention capacity in the pots without polymer reached $20-25 \%$ of the maximum. Water was then added to all pots until it started trickling from the bottom of the pot.

Plant shoots were cut 41, 62, 82 and 101 days after sowing, washed with de-ionized water, dried at $65^{\circ} \mathrm{C}$ and weighed. After each cut, another $100 \mathrm{mg} \mathrm{N} / \mathrm{kg}$ of soil, as ammonium nitrate, was added as a top dressing.

At the end of the experiment, the soil was passed through a 2-mm sieve. Fresh soil subsamples were analysed for dehydrogenase activity according to Tabatabai (1994), for culturable heterotrophic bacteria by plating in a 'Nutrient' and yeast extract agar, and for culturable fungi by plating in a malt and yeast extract with rifampicin, according to Pochon \& Tardieux (1962), with incubation periods of $48 \mathrm{~h}$ at $27^{\circ} \mathrm{C}$ for bacteria and 7 days at $27^{\circ} \mathrm{C}$ for fungi.

Other soil subsamples were frozen until analysed for several enzymatic activities. Cellulases were determined according to Hope \& Burns (1987). Cellulases are enzyme systems that degrade cellulose and release reducing sugars as the end product. In the context of this study, the term refers to the combined action of endo-1,4- $\beta$-D-glucanase (EC 3.2.1.4), exo1,4- $\beta$-D-glucanase (EC3.2.1.91) and $\beta$-D-glucosidase (EC 3.2.1.21) on Avicel, a purified depolymerized alpha cellulose.

Acid phosphomonoesterase (EC 3.1.3.2) and $\beta$-glucosidase (EC 3.2.1.21) were measured by incubating the soil with a substrate containing a $p$-nitrophenyl moiety according to Eivazi \& Tabatabai (1977, 1988). Acid phosphomonoesterase (acid phosphatase) catalyses the hydrolysis of organic $\mathrm{P}$ esters and anhydrides of phosphoric acid into inorganic $\mathrm{P}$. $\beta$-glucosidase is involved in the final step of cellulose degradation and catalyses the hydrolysis of carbohydrates with $\beta$-D-glucoside bonds like cellobiose, providing energy substrates for soil heterotrophic microorganisms. 
Urease (EC 3.5.1.5) was determined according to Kandeler \& Gerber (1988). Urease catalyses the hydrolysis of urea to $\mathrm{CO}_{2}$ and $\mathrm{NH}_{3}$.

Proteases were measured according to Ladd \& Butler (1972) using casein as substrate. The term includes several enzymes that catalyze the hydrolysis of proteins and oligopeptides to amino acids.

A subsample of the soil from each pot was air-dried and analysed for $\mathrm{pH}$ in water $(1: 2.5)$ and $\mathrm{CaCl}_{2}$-extractable $\mathrm{Pb}$. Soil samples $(4 \mathrm{~g})$ were shaken with $40 \mathrm{~cm}^{3}$ of $0.01 \mathrm{M} \mathrm{CaCl}_{2}$ for $2 \mathrm{~h}$. The extract was filtered through Whatman No. 6 paper and analysed for $\mathrm{Pb}$ by atomic absorption spectrophotometry with a graphite furnace.

\section{Statistics}

All data were analysed for variance by the general linear model and mean separation was performed using the Newman-Keuls test at $P \leq 0.05$. Principal component analysis (PCA) and cluster analysis were performed to detect the key parameters contributing to data variability, and compare the effects of treatments to identify the best level of polymer to use in soil remediation.

\section{Results}

\section{Water content}

The maximum water-holding capacity of the unamended soil was about $250 \mathrm{~g} / \mathrm{kg}$ (1000 g per pot). The incorporation of $0.2 \%$ polymer increased the water-holding capacity to about twice that value at the beginning of the experiment. This capacity decreased progressively, so that at the end of the experiment, the soil retained only about $20 \%$ more water than the unamended control (Figure 1).

Because of volume limitation, the pots with soil that received 0.4 or $0.6 \%$ polymer could not be brought to full water-holding capacity at the beginning of the experiment. The water supplied was increased daily as polymer swelling

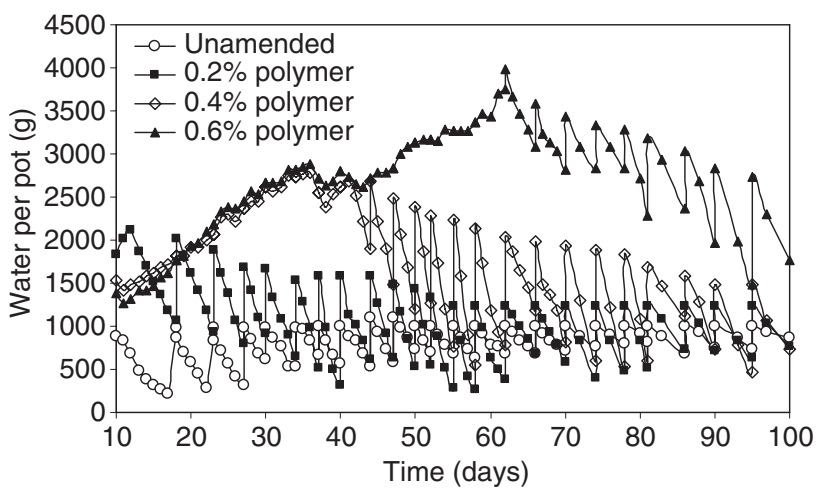

Figure 1 Effect of the concentration of polyacrylate polymers on the amount of water in each pot containing contaminated soil. decreased and more space became available in the pots, until the water applied was enough to saturate the soil and polymer. This occurred about 35 and 60 days after the beginning of the experiment for soil with 0.4 and $0.6 \%$ polymer, respectively (Figure 1).

The maximum water-holding capacity of the soil with $0.4 \%$ polymer varied from 690 to $370 \mathrm{~g} / \mathrm{kg}$ during the experiment, and the equivalent values for soil with $0.6 \%$ polymer were 1000 and $680 \mathrm{~g} / \mathrm{kg}$, respectively.

\section{Plant growth}

Plants from unamended soil grew poorly, and had thin chlorotic leaves that became progressively necrotic. Growth of orchardgrass in amended soil was always greater than in unamended soil (Figure 2). In the first cut, the greatest shoot biomass corresponded to plants grown in soil that had received $0.2 \%$ of polymer, while in the second and third cuts the greatest biomass was obtained in treatments with $0.4 \%$ polymer. In the fourth cut, the treatments corresponding to 0.4 and $0.6 \%$ polymer led to similar plant biomass.

The greatest accumulated biomass over the four cuts was obtained in plants grown in soil with $0.4 \%$ polymer $(31.0 \mathrm{~g}$ per pot), which was more than 3000 times greater than biomass of plants from soil with no polymer.

\section{Soil parameters}

The soil $\mathrm{pH}$ increased from 3.8 in unamended soil to 6.0 in soil that received $0.6 \%$ polymer (Table 2 ). After plant growth for 101 days, the amount of $\mathrm{CaCl}_{2}$-extractable $\mathrm{Pb}$ in the unamended soil was 1.6-6.7 times greater than that from soil amended with 0.4 and $0.6 \%$ polymer, respectively (Table 2).

The number of culturable bacteria and the activities of acid phosphatase, $\beta$-glucosidase and cellulase increased with polymer application rate (Tables 2 and 3), while the number of culturable fungi was greatest in soil amended with $0.2 \%$ polymer, and similar in the other treatments (Table 2). Thus bacterial numbers responded more to polymer application than fungal numbers, likely as a result of enhanced water content and higher $\mathrm{pH}$. It is well known that fungi are more tolerant of acid conditions and less sensitive to soil moisture levels than bacteria (Doran, 1980).

The dehydrogenase activity was greatest in soil amended with 0.2 and $0.4 \%$ polymer, and the protease activity was considerably enhanced in amended soil, irrespective of polymer level (Table 3). In contrast, the urease activity was inhibited by polymer application, with the smallest values in soil amended with 0.2 and in particular in soil with $0.4 \%$ polymer (Table 3 ).

\section{Comparison between treatments}

Principal component analysis was carried out on plant biomass and 10 soil variables to assess the influence of each 
Figure 2 Effect of the concentration of polyacrylate polymers on shoot biomass removed at each cut (left) or accumulated biomass (right) of orchardgrass grown in contaminated soil.

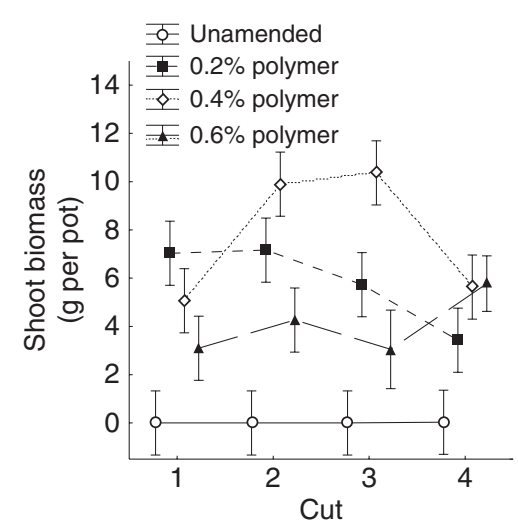

Table 2 Effect of the concentration of polyacrylate polymers on soil $\mathrm{pH}$, number of culturable heterotrophic bacteria and fungi, and $\mathrm{CaCl}_{2}$-extractable $\mathrm{Pb}$ at the end of the experiment

\begin{tabular}{lcccc}
\hline $\begin{array}{l}\text { Level of } \\
\text { polymer (\%) }\end{array}$ & $\mathrm{pH}$ & $\begin{array}{c}\text { Bacteria } \\
\mathrm{CFU} \times 10^{5} / \mathrm{g}\end{array}$ & $\begin{array}{c}\text { Fungi } \\
\mathrm{CFU} \times 10^{5} / \mathrm{g}\end{array}$ & $\begin{array}{c}\text { Extractable } \\
\mathrm{Pb}(\mathrm{mg} / \mathrm{kg})\end{array}$ \\
\hline 0 & $3.8 \mathrm{c}$ & $7 \mathrm{c}$ & $2 \mathrm{~b}$ & $0.87 \mathrm{a}$ \\
0.2 & $4.0 \mathrm{bc}$ & $67 \mathrm{~b}$ & $19 \mathrm{a}$ & $0.57 \mathrm{~b}$ \\
0.4 & $4.3 \mathrm{~b}$ & $70 \mathrm{~b}$ & $9 \mathrm{~b}$ & $0.55 \mathrm{~b}$ \\
0.6 & $6.0 \mathrm{a}$ & $250 \mathrm{a}$ & $7 \mathrm{~b}$ & $0.13 \mathrm{c}$ \\
\hline
\end{tabular}

Values in a column followed by the same letter are not significantly different as estimated by the Newman-Keuls test at $P<0.05$. CFU, colony forming units.

treatment on soil quality. The accumulated biomass, $\mathrm{pH}$, bacterial numbers and activities of cellulase, phosphatase, $\beta$-glucosidase and protease had large positive loading coefficients on $\mathrm{PC} 1$. Urease activity and $\mathrm{CaCl}_{2}$-extractable $\mathrm{Pb}$ had large negative loadings on PC1. Fungal numbers and dehydrogenase activity had large positive loadings on PC2 (Table 4).

The first component (PC1) explained 59.8\% and the second component (PC2) $24.0 \%$ of the variance of the original variables. The 11 variables could thus be reduced to two principal components, as they explained about $84 \%$ of the total variance. Unamended soil was located on the left side of the PCA map, with Euclidian distances between replicates smaller than 0.2 , but separated from amended soil by the Euclidian distance of almost two (Figure 3). This meant that unamended soil was uniform and had very different values for parameters with high loadings on $\mathrm{PCl}$ compared with amended soil samples, which were located on the centre or the right side of the map.

The treatments corresponding to 0.2 and $0.4 \%$ polymer were located on the upper side of the map, in the positive part of $\mathrm{PC} 2$, with the Euclidian distance between them of about 0.5 . The treatment corresponding to $0.6 \%$ polymer was on the positive side of $\mathrm{PC} 1$ but on the negative side of $\mathrm{PC} 2$, with the Euclidian distance to the treatments corresponding to 0.2 and $0.4 \%$ polymer of about 1.8 .

\section{Discussion}

Natural background concentrations of $\mathrm{Cu}, \mathrm{Zn}$ and $\mathrm{Pb}$ in soils range from 2-200, 10-300 and 10-200 mg/kg, respectively (Srivastava \& Gupta, 1996). The mine soil can be considered as contaminated with $\mathrm{Pb}$, but not with $\mathrm{Cu}$ or $\mathrm{Zn}$. It seems probable that copper extraction removed most of the $\mathrm{Cu}$ and probably part of the $\mathrm{Zn}$ originally present. In consequence, only the changes in soil $\mathrm{Pb}$ were monitored in the present work.

Soil $\mathrm{Pb}$ levels above $530 \mathrm{mg} / \mathrm{kg}$ ('Interventional Level') are considered to be toxic for humans, plants and soil organisms according to the Dutch Soil Protection Law (Broos et al., 1999). The level of total $\mathrm{Pb}$ present in the soil used in this experiment $(6200 \mathrm{mg} / \mathrm{kg}$ soil) is indicative of extreme pollution, and the site can even be considered as 'chemical waste' (Broos et al., 1999). It is therefore not surprising that a vegetation cover could not be established in unamended soil. Orchardgrass grew very poorly and the plants became progressively necrotic.

Irregular rainfall in the region where the mine is located is a further limitation for the establishment of plants. In the present experiment, we tested if the application of hydrophilic polyacrylate polymers could overcome these two constraints: high levels of $\mathrm{Pb}$ and water stress.

The polymers used had $\mathrm{K}^{+}$and $\mathrm{NH}_{4}{ }^{+}$as counter ions. To make sure that plant growth would not be stimulated by increased supply of nutrients, the total amount of $\mathrm{K}$ and $\mathrm{N}$ applied to the soil, either as mineral fertilizer or as part of the polymers, was the same in all treatments. We assumed that the nutrients in the polymers had the same bioavailability as that directly applied to soil, as already shown in a previous work (de Varennes et al., 2006). In consequence, the effects observed should result from differences in water supply and bioavailability of trace elements.

To simulate dryland conditions, enough water was supplied to saturate the soil (and polymer) but with intervals of 
Table 3 Effect of the concentration of polyacrylate polymers on enzymatic activities in contaminated soil at the end of the experiment

\begin{tabular}{|c|c|c|c|c|c|c|}
\hline $\begin{array}{l}\text { Level of } \\
\text { polymer }(\%)\end{array}$ & Dehydrogenase & Phosphatase & $\beta$-glucosidase & Urease & Protease & Cellulase \\
\hline 0 & $0.45 \mathrm{~b}$ & $0.354 \mathrm{c}$ & $0.087 \mathrm{~d}$ & $10.79 \mathrm{a}$ & $<0.001 \mathrm{~b}$ & $0.012 \mathrm{~d}$ \\
\hline 0.4 & $1.50 \mathrm{a}$ & $0.664 \mathrm{~b}$ & $0.287 \mathrm{~b}$ & $0.21 \mathrm{~d}$ & $0.011 \mathrm{a}$ & $0.131 \mathrm{~b}$ \\
\hline 0.6 & $0.81 \mathrm{~b}$ & $1.151 \mathrm{a}$ & $0.320 \mathrm{a}$ & $2.67 \mathrm{~b}$ & $0.016 \mathrm{a}$ & $0.182 \mathrm{a}$ \\
\hline
\end{tabular}

Values in a column followed by the same letter are not significantly different as estimated by the Newman-Keuls test at $P<0.05$; units of enzyme activity: dehydrogenase $-\mu \mathrm{g}$ triphenylformazan/g 16h; acid phosphatase and $\beta$-glucosidase $-\mu$ mol $\mathrm{p}$-nitrophenol/gh; urease $-\mu \mathrm{g}$ $\mathrm{NH}_{4}{ }^{+}-\mathrm{N} / \mathrm{g} 2 \mathrm{~h}$; protease $-\mu \mathrm{mol}$ tyrosine/g $2 \mathrm{~h}$; cellulase $-\mu \mathrm{mol}$ glucose/g $16 \mathrm{~h}$.

Table 4 Loadings for each variable along PC1 and PC2 which resulted from principal component analysis

\begin{tabular}{lrr}
\hline Variable & PC1 & PC2 \\
\hline Accumulated biomass & $0.7967^{\mathrm{a}}$ & 0.5597 \\
Urease activity & $-0.8779^{\mathrm{a}}$ & -0.4497 \\
$\mathrm{pH}$ & $0.7054^{\mathrm{a}}$ & -0.6379 \\
$\mathrm{CaCl}_{2}$-extractable $\mathrm{Pb}$ & $-0.8721^{\mathrm{a}}$ & 0.2099 \\
Cellulase activity $_{\text {Dehydrogenase activity }}$ & $0.9279^{\mathrm{a}}$ & -0.2163 \\
Phosphatase activity & 0.5223 & $0.7652^{\mathrm{a}}$ \\
Glucosidase activity & $0.7415^{\mathrm{a}}$ & -0.4383 \\
Protease activity & $0.8591^{\mathrm{a}}$ & -0.0875 \\
Bacteria & $0.9428^{\mathrm{a}}$ & 0.0267 \\
Fungi & $0.7485^{\mathrm{a}}$ & -0.5295 \\
& 0.1028 & $0.7431^{\mathrm{a}}$ \\
\hline
\end{tabular}

PC1, first principal component; PC2, second principal component.

${ }^{a}$ Correlations are significant (correlation coefficient $>0.7$ ).

several days between irrigations. These took place when the control pots with unamended soil reached a weight corresponding to $20-25 \%$ of their maximum water-holding capacity. In this way, plants should suffer from water stress, as is common in Mediterranean conditions, unless the polymer was able to retain and provide additional water. Following polymer application, the maximum water-holding capacity increased from $250 \mathrm{~g} / \mathrm{kg}$ in unamended soil to $1000 \mathrm{~g} / \mathrm{kg}$ in soil with $0.6 \%$ polymer. This additional water contributed no doubt to enhanced plant growth. However, it might also have impaired air permeability and oxygen availability to roots. This was probably the reason why plant biomass in the first cut was smaller in treatments corresponding to higher levels of polymer than in the treatment with $0.2 \%$ polymer.

The water-holding capacity of the amended soil decreased progressively, presumably as a result of polymer collapse due to chelation of $\mathrm{Pb}$ (de Varennes \& Torres, 2000). The joint effect of the polymer on soil $\mathrm{pH}$ (an increase from 3.8 in unamended soil to 6.0 in soil with $0.6 \%$ polymer) and sorption of trace elements should decrease their bioavailability, and in fact the amount of $\mathrm{CaCl}_{2}$-extractable $\mathrm{Pb}$ decreased in amended soil (Table 2).

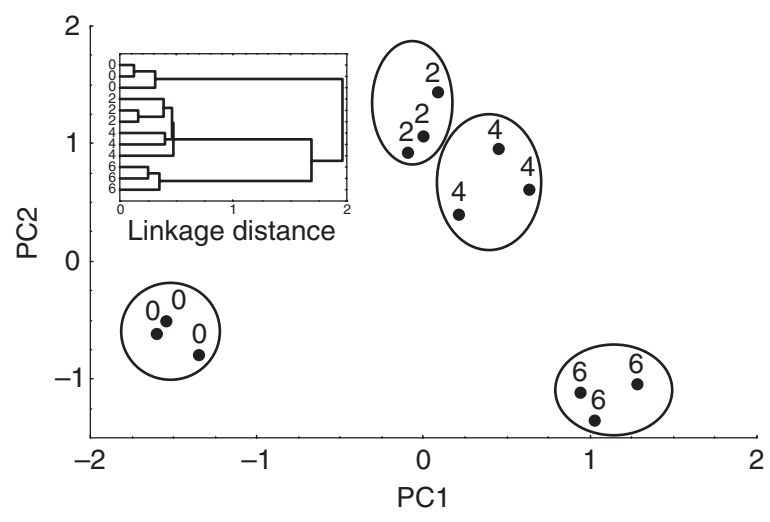

Figure 3 Principal Component Analysis and Cluster Analysis (inset) of treatments at the end of the experiment. $0,2,4$ and 6 - unamended soil or with $0.2 \%, 0.4 \%$ and $0.6 \%$ of polyacrylate polymers, respectively; $\mathrm{PC} 1$ and $\mathrm{PC} 2$ - principal components 1 and 2, respectively.

The increase in soil $\mathrm{pH}$ was presumably because of the exchange of counter ions present in the polymer $\left(\mathrm{K}^{+}\right.$and $\mathrm{NH}_{4}{ }^{+}$) for acidic ions in soil solution, as observed before (de Varennes \& Torres, 1999).

$\mathrm{CaCl}_{2}$-extractable metals are considered as the mobile fraction, also referred as the 'effective bioavailable metal fraction' (Pueyo et al., 2004). This fraction is actually more important than the total content of metals, as plant uptake will take place from this pool. Application of polyacrylate polymers reduced bioavailable $\mathrm{Pb}$ from 15 to $66 \%$ of those in the unamended soil, depending on the polymer application rate.

The soil environment became more favourable for plant growth, as $\mathrm{Pb}$ was removed from soil solution and the access to water and oxygen became more balanced. In consequence, in the fourth cut the greatest plant biomass was obtained in treatments with 0.4 and $0.6 \%$ polymer.

Enhanced plant growth with a corresponding increase in root exudates that supply $\mathrm{C}$ to soil organisms, and the smaller bioavailability of $\mathrm{Pb}$ should stimulate microbial activity and soil enzymes. Most soil enzymes are inhibited by high levels of trace metals in soils (Kandeler et al., 1997; Huang \& Shindo, 2000; Belén-Hinojosa et al., 2004). With the exception of urease, all soil biological parameters responded 
to treatments and their values were greater in amended soil than in control.

Principal component analysis was used to compare the effect of each treatment on soil quality. The top right of the PCA map corresponded to the greatest values of plant biomass, soil $\mathrm{pH}$, activities of dehydrogenase, cellulase, acid phosphatase, $\beta$-glucosidase, protease, number of culturable bacteria and fungi and smallest value of $\mathrm{CaCl}_{2}$-extractable $\mathrm{Pb}$ and urease activity (Table 4). With the exception of urease, whose activity was depressed by polymer application, presumably due to the presence of ammonium as the counter ion, all the other indicators suggest that the further to the right and top of the PCA map a treatment is located the greater the quality of the soil.

The three replicates of each treatment were closely grouped (Euclidian distances $<0.5$ ), while these groups were located in different positions on the PCA map, with Euclidian distances between them $\geq 0.6$. The controls were situated on the left of the map (Figure 3). The greater the polymer application rate, the further to the right and bottom of the map was the treatment located, i.e. towards the positive side of $\mathrm{PC} 1$ and negative side of PC2. This meant that no treatment could be considered superior to others. The treatments corresponding to 0.2 and $0.4 \%$ polymer were closer (Euclidian distance between them of about 0.5 ) than control or the treatment corresponding to $0.6 \%$ polymer (Euclidian distances $>1.5)$. These treatments $(0.2$ and $0.4 \%$ polymer) were the only treatments that were located on the positive side of $\mathrm{PC} 2$, and were considered the application rates that represented the best balance between the effects of polymer on water supply, plant growth and soil quality.

Many remediation methods have been proposed, and it is difficult to choose the most appropriate technology for a particular site. In the case of severely contaminated soils, the main emphasis has to be put on the establishment of a vegetation cover to prevent wind erosion and decrease run-off and leaching.

Controlling metal availability by liming is insufficient in pyrite sites as these have the potential to generate further acidity (Scullion, 2006).

Application of composts or biosolids is common, and will remain a popular method. They usually increase plant growth by providing nutrients and adsorbing metals, but after degradation of the organic matter, the metals become available again to plants and soil organisms. They might even increase the bioavailability of some metals (Clemente et al., 2003). In contrast, polyacrylate polymers are more stable in soils, although they can also be slowly degraded by white-rot fungi (Cameron \& Aust, 1999).

The main advantage of polyacrylate polymers over other amendments is that they seem to provide a microcosm, rich in water and with lower concentrations of trace elements, where roots and microorganisms can proliferate.
The comparative analysis of costs between different remediation technologies is hampered by the lack of reports on long-term remediation experiments. Conventional engineering approaches are said to cost between $\$ 50$ and $\$ 500$ per ton of soil (Cunningham \& Ow, 1996), while Salt et al. (1995) reported that remediation of one acre of land using phytoextraction would cost between $\$ 60000$ and $\$ 100000$, compared with $\$ 400000$ for soil excavation and storage alone.

In general, in situ remediation is considered less expensive than ex situ remediation. Polyacrylate polymers cost about 2 Euros $/ \mathrm{kg}$, corresponding to a cost of 8 Euros/ton of soil if a rate of $0.4 \%$ was used. Moreover, the polymers could be applied in sowing rows only, decreasing even further the cost. This cost is very favourable when compared to engineering approaches or the simple excavation and storage of the soil. It is also less expensive than phytoextraction. However, the aims of these methods are very different and apply to soils with contrasting levels of contamination. It would be impossible to remediate a mine soil using phytoextraction because it would be too costly and time-consuming. Therefore, the use of polyacrylate polymers seems an attractive and inexpensive alternative to other remediation methods for severely contaminated sites in locations with irregular rainfall.

\section{Conclusions}

We showed that the application of insoluble hydrophilic polyacrylate polymers can be considered a new method for in situ remediation of mine soils. Polymer application rates of $0.2-0.4 \%$ were considered sufficient as they led to a large improvement in plant growth and soil quality.

\section{Acknowledgements}

This study was funded by the project PPCDT/ AMB/57586/2004 from the Portuguese Foundation for Science and Technology (FCT). We thank Paula Gonçalves Silva for technical assistance. Qu Guiwei is grateful for the grant (SFRH/BD/21430/2005) from FCT.

\section{References}

Al-Humaid, A.I. \& Moftah, A.E. 2007. Effects of hydrophilic polymers on the survival of buttonwood seedlings grown under drought stress. Journal of Plant Nutrition, 30, 53-66.

Belén-Hinojosa, M., Garcia Ruiz, R., Venegla, B. \& Carreira, J.A. 2004. Microbiological rates and enzyme activities as indicators of functionality in soils affected by the Aznalcollar toxic spill. Soil Biology and Biochemistry, 36, 1637-1644.

Boatright, J.L., Balint, D.E., Mackay, W.A. \& Zajicek, J.M. 1997. Incorporation of a hydrophilic polymer into annual landscape beds. Journal of Environmental Horticuture, 15, 37-40.

Broos, M.J., Aarts, L., van Tooren, C.F. \& Stein, A. 1999. Quantification of the effects of spatially varying environmental conta- 
minants into a cost model for soil remediation. Journal of Environmental Management, 56, 133-145.

Cameron, M.D. \& Aust, S.D. 1999. Degradation of chemicals by reactive radicals produced by cellobiose dehydrogenase from Phanerochaete chrysosporium. Archives of Biochemistry and Biophysics, 367, 115-121.

Clemente, C., Walker, D.J., Roig, A. \& Bemal, M.P. 2003. Heavy metal bioavailability in a soil affected by mineral sulphide contamination following the mine spillage at Aznalcollar (Spain). Biodegradation, 14, 199-205.

Cunningham, S.D. \& Ow, D.W. 1996. Promises and prospects of phytoremediation. Plant Physiology, 110, 715-719.

Doran, J.W. 1980. Microbiological changes associated with residue management with reduced tillage. Soil Science Society of America Journal, 44, 518-524.

Eivazi, F. \& Tabatabai, M.A. 1977. Phosphatases in soils. Soil Biology and Biochemistry, 9, 167-172.

Eivazi, F. \& Tabatabai, M.A. 1988. Glucosidases and galactosidases in soils. Soil Biology and Biochemistry, 20, 601-606.

Farfel, M.R., Orlova, A.O., Chaney, R.L., Lees, P.S.J., Rohde, C. \& Ashley, P. 2005. Biosolids compost amendment for reducing soil lead hazards: a pilot study in urban yards. Science of the Total Environment, 340, 81-95.

Friesl, W., Lombi, E., Horak, O. \& Wenzel, W. 2003. Immobilization of heavy metals in soils using inorganic amendments in a greenhouse study. Journal of Plant Nutrition and Soil Science, 166, 191-196.

Geebelen, W., Adriano, D.C., van der Lelie, D., Mench, M., Carleer, R., Clijsters, H. \& Vangronsveld, J. 2003. Selected bioavailability assays to test the efficacy of amendment-induced immobilization of lead in soil. Plant and Soil, 249, 217-228.

Hope, C.F.A. \& Burns, R.G. 1987. Activity, origins and location of cellulase in a silt loam soil. Biology and Fertility of Soils, 5, 164-170.

Huang, Q. \& Shindo, H. 2000. Effects of copper on the activity and kinetics of free and immobilized acid phosphatase. Soil Biology and Biochemistry, 32, 1885-1892.

Kandeler, E. \& Gerber, H. 1988. Short-term assay of soil urease activity using colorimetric determination of ammonium. Biology and Fertility of Soils, 6, 68-72.

Kandeler, E., Kampichler, C. \& Horak, O. 1997. Influence of heavy metals on the functional diversity of soil microbial communities. Biology and Fertility of Soils, 23, 299-306.

Ladd, J.N. \& Butler, J.H.A. 1972. Short-term assays of soil proteolytic enzyme activities using proteins and dipeptide derivatives as substrates. Soil Biology and Biochemistry, 4, 19-30.

Lindim, C., de Varennes, A., Torres, M.O. \& Mota, A.M. 2001. Remediation of a sandy soil artificially contaminated with cad- mium using a polyacrylate polymer. Communications in Soil Science and Plant Analysis, 32, 1567-1574.

Martin, E. 1996. Environmental impact studies of the disposal of polyacrylate polymers used in consumer products. Science of the Total Environment, 19, 225-234.

Pochon, J. \& Tardieux, P. 1962. Techniques d'analyse en microbiologie du sol. La Tourelle, Saint Mandé (Seine), France.

Pueyo, M., López-Sanchez, J.F. \& Rauret, G. 2004. Assessment of $\mathrm{CaCl}_{2}, \mathrm{NaNO}_{3}$ and $\mathrm{NH}_{4} \mathrm{NO}_{3}$ extraction procedures for the study of $\mathrm{Cd}, \mathrm{Cu}, \mathrm{Pb}$ and $\mathrm{Zn}$ extractability in contaminated soils. Analytica Chimica Acta, 504, 217-226.

Salt, D.E., Blaylock, M., Kumar, P.B.A.N., Dushenkov, V., Ensley, B.D., Chet, I. \& Raskin, I. 1995. Phytoremediation: a novel strategy for the removal of toxic metals from the environment using plants. Biotechnology, 13, 468-475.

Scullion, J. 2006. Remediating polluted soils. Naturwissenschaften, 93, 51-65.

Silberbush, M., Adar, E. \& de Malach, Y. 1993. Use of a hydrophilic polymer to improve water storage and availability to crops grown in sand dunes I. Corn irrigated by trickling. Agricultural Water Management, 23, 303-313.

Srivastava, P.C. \& Gupta, U.C. 1996. Trace elements in crop production. Science Publishers Inc., Lebanon, NH, USA.

Tabatabai, M.A. 1994. Soil enzymes. In: Methods of soil analysis, Part 2 (eds S.H. Mickelson \& J.M. Bigham), pp. 775-833. Soil Science Society of America, Madison, WI, USA.

Torres, M.O. \& de Varennes, A. 1998. Remediation of a sandy soil artificially contaminated with copper using a polyacrylate polymer. Soil Use and Management, 14, 106-110.

de Varennes, A. \& Queda, C. 2005. Application of an insoluble polyacrylate polymer to copper-contaminated soil enhances plant growth and soil quality. Soil Use and Management, 21, 410-414.

de Varennes, A. \& Torres, M.O. 1999. Remediation of a long-term copper-contaminated soil using a polyacrylate polymer. Soil Use and Management, 15, 230-232.

de Varennes, A. \& Torres, M.O. 2000. Soil remediation with insoluble polyacrylate polymers: an overview. Revista de Ciências Agrárias, 23, 13-22.

de Varennes, A., Torres, M.O., Conceição, E. \& Vasconcelos, E. 1999. Effect of polyacrylate polymers with different counter ions on the growth and mineral composition of perennial ryegrass. Journal of Plant Nutrition, 22, 33-43.

de Varennes, A., Goss, M.J. \& Mourato, M. 2006. Remediation of a sandy soil contaminated with cadmium, nickel and zinc using an insoluble polyacrylate polymer. Communications in Soil Science and Plant Analysis, 37, 1639-1649. 